\title{
Comparisons of performances for determining the relative importance in the modem pentathlon
}

\author{
Seung-hun Lee ${ }^{1}$, Jong-chul Park ${ }^{2}$, Ki-bum Kim ${ }^{1}$, Sung-jin Kim ${ }^{3}$, \& Byoung-goo Ko ${ }^{1}$ * \\ ${ }^{1}$ Korea Institute of Sport Science, ${ }^{2}$ Pukyong National University, $\&{ }^{3}$ Korea Modern Pentathlon Federation
}

\begin{abstract}
[Purpose] The purpose of this study was to compare the official world records of UIPM in the last 3 years to find out the relationship between the score characteristics of fencing, swimming, equestrian, and laser-run events in the final rankings and to analyze the relative importance of each event. [Methods] For 3 years, from 2017 to 2019, a total of the data were collected, the final rankings, fencing conversion scores, swimming conversion scores, equestrian scores, and laser-run conversion scores for all male and female athletes who participated in the UIPM Level 1 World Cup and World Championships(1,197 finals and 2,173 qualifiers). The Multiple regression analysis was used to establish the relationship between the response(subjective) variable and the conversion score of the four explanatory(independent) variables. [Results] The results were compared by qualification $(n=2173)$ and final $(\mathrm{n}=1197)$ by dividing into male $(\mathrm{n}=1179)$ and female $(\mathrm{n}=1591)$, and the fencing score was qualifications (male $\beta=-.691$, female $\beta=-.533$ ) and the finals (male $\beta=-.632$, female $\beta=-.632$ ), it showed the greatest influence in all. On the other hand, the swim score showed the lowest impact on both qualifications (male $\beta=-.021$, female $\beta=-.196$ ) and finals (male $\beta=-.087$, female $\beta=-$. 207). The fencing event plays a major role in passing the qualifiers and is a big variable for good performance in the finals. On the other hand, in the case of swimming scores, both men and women had the lowest impact on the final ranking, and there is a limit to the final performance of swimming scores in both qualifiers. [Conclusion] In conclusion, it is necessary to analyze and systemize the fencing skills of the world's best athletes, including Korean athletes, to improve the Korean fencing athletes' performance, and through such scientific analysis, a system that enables fast and flexible responses to the upcoming Olympic. Additionally, even though the importance of all sports should be levelled due to the characteristics of modern pentathlon, relative importance is biased toward fencing and swimming events are neglected. Therefore, it is deemed necessary to conduct a follow-up study on whether the scoring system in modern pentathlon consists of a scoring system that supports the records of each event and the upper and lower scoring system.
\end{abstract}

Key words: Modern Pentathlon, Elite Athletes, Relative Importance, Performance Analysis, Sports Big Data

논문 투고일 : 2020. 05. 15.

논문 수정일 : 2020. 07. 06.

게재 확정일 : 2020. 07. 30.

* 교신저자 : 고병구(bgko@ kspo.or.kr).

\section{서 론} \\ 근대 5 종 경기는 1912 년 제 5 회 스웨덴 스톡홀름 올림 \\ 픽 때부터 시행되고 있는 전통적인 올림픽 정식종목이다. \\ 1964년 제18회 도쿄올림픽에 근대5종 대표선수로 최귀
}


승이 출전한 이후 불모지와 다름없었던 대한민국에 근대 5 종이 점진적인 성장을 거듭해왔다(Park et al, 2017),

근대5종 경기는 펜싱 (에페), 수영 ( $200 \mathrm{~m}$ 자유형), 승 마(장애물), 육상 $(3.2 \mathrm{~km})$, 사격 $(10 \mathrm{~m})$ 등 총 5 개 종목에 서 득점한 점수를 합산하여 총점으로 순위를 정하는 복합 경기이다(Kim et al, 2018). 2009년 이전 사격, 펜싱, 수영, 승마, 육상 순이었으나 2008년 11월 과테말라에서 개최된 세계근대 5 종 연맹 정기총회에서 복합경기방식으 로 경기규칙을 개정하였다(Han, 2009). 개정된 경기규 칙은 2009년부터 시행되었는데(Sandra, 2014), 펜싱, 수영, 승마, 레이저런(사격\&육상)경기 순으로 변경되었 다. 세계대회에서는 하루에 5 종목을 전부 실시하는 것을 원칙으로 하지만 올림픽에서는 미디어의 영향으로 펜싱 예선라운드를 먼저 치른다(Sandra, 2013). 5개의 종목 마다 1,000 점이 되는 표준기록이 설정되어 그 표준에 의 해 성적이 산출되는데 표준보다 낮은 점수가 되면 감점, 높은 점수를 얻으면 득점이 되는 방식이다(Skitnevskiy, 2018). 펜싱, 수영, 승마경기가 종료되면 종합득점이 시 간(초)으로 환산된다. 그 결과로 레이저런의 스타트순서 와 지연시간이 결정되어 핸디캡 스타트를 적용시켜 가장 빠르게 결승점을 통과한 승자가 5 종 경기의 최종 우승자 가 된다(Heck, 2014). 개인경기와 단체경기, 계주 (Relay)경기가 있으며, 대인(對人) 경기는 펜싱뿐이고 나머지 4종목은 기록 경기라는 점이 특징이다. 5 가지 종 목 중 수영, 승마, 레이저런 경기는 기록 경기이고 펜싱종 목은 유일한 상대성 경기이기 때문에 펜싱 경기의 기록에 따라 복합경기에서 출발순서에 미치는 영향력이 크다 (Cohal, 2019).

펜싱 점수는 환산 점수표에 의해 주어지는데 국제 근대 5종연맹(UIPM: Union International de Pentathlon Modern)Level 1 경기 (월드컵, 세계선수권, 올림픽)결승 은 36명이 참가해 1승에 6점차이가 주어진다. 수영은 2017년 이전에는 0.33초에 1점(1초에 3점)의 감점이 주 어졌지만 2017년 이후 0.5초에 1점(1초에 2점)의 감점 으로 수영 점수 환산 규정이 변경되었다(KMPF, 2018). 승마는 장애물 비월경기로서 승마 주행경로에 비월 장애 물 12개(싱글10개, 더블1개, 트리플1개)가 설치된 $400 \mathrm{~m} \sim 450 \mathrm{~m}$ 코스를 완주하여야 한다. 소정시간에 장 애물을 무 감점으로 통과한 선수에게 300점을 부여한다
(Pentathlon, 2015). 레이저런(육상, 사격)출발방법은 이전 3개 경기 종목의 종합점수를 기준으로 시간차이 (1 점당 1 초)를 두고 출발하는 핸디캡 스타트 방식을 적용한 다(Chirico, 2019).

경기의 특성상 각 종목별 개인기록과 점수 관리가 경 기 결과에 직접적인 영향을 줄 수 있으며, 각 경기 종목별 기록에 의한 환산점수로 순위가 결정되므로 이에 대해 정 확한 자료를 확보하는 것이 선수들이 기록을 관리 하는데 있어 주요한 요인이 될 수 있다(Lee \& An, 2012). 이를 위한 종합적이고 체계적인 종목별 기록과 점수의 비교가 반드시 이뤄져야 할 필요가 있다(Park \& Lee, 2020).

지금까지 근대 5 종과 관련한 연구는 생리학, 심리학 및 트레이닝 방법론에 대부분 치우쳐 있는데 (Kim et al, 2018), 경기력 향상을 위한 경기 기록과 관련된 연구를 살펴보면 Lee \& An(2012)은 근대5종 선수들의 사격, 수영, 육상의 세계 기록 및 국내 기록 변화 비교 연구를 통해 종목별 개인차를 고려한 기술 및 체력훈련의 필요성 을 강조하였고, Han \& Choi(2016)는 근대5종 경기규칙 개정 전후의 경기기록 분석 연구를 통해 국내선수들의 수 준별 경기기록의 변화를 보고했다. Park \& Lee(2020) 는 5년간 전체 사격 데이터를 통해 왕복횟수와 차수가 늘 어날수록 사격누적기록이 나빠지는 양상을 보였으며, 근 대5종 복합경기 기록 단축을 위해서는 사격 종목 기량 향 상을 위한 다양한 노력이 필요하다고 강조했다.

스포츠 경기를 과학적으로 분석하는 것은 선수나 팀의 경기력 향상과 함께 향후 훈련계획을 수립하는데 많은 도 움을 주고 있다. 특히 경기력을 향상시키기 위해서는 객 관적이고 체계적인 경기내용에 대한 분석이 필요한데, 이 러한 분석을 통하여 경기력이나 승패에 영향을 주는 요인 들을 추출해 낼 수 있기 때문이다(Hughes \& Franks, 2004). 체계적인 기록·분석을 위한 이론적, 기술적 발전 은 스포츠 경기에 큰 비중을 차지해가고 있으며 $(\mathrm{Kim} \&$ Choi, 2008), 최근에는 스포츠 분야에도 '빅데이터 (Bigdata)' 기술이 적용되어 정형 또는 비정형화된 데이 터에서 대량의 가치를 찾아 결과예측을 하는 등의 발전을 보이고 있다(Choi \& Lee, 2020).

최근까지 근대5종 경기에 대한 경기력의 평가는 점수 로 환산했을 때의 최고 점수를 파악하는데 그쳤고, 장기 간의 경기기록과 점수에 대한 변화를 살펴보고자 한 연구 
는 미비하다. 또한 대부분이 국내선수를 대상으로 단기간 의 데이터를 바탕으로 이루어졌으며, 세계 우수 선수들의 데이터가 바탕이 된 연구는 미비했다. 근대 5 종 종목은 5 개 세부종목의 경기력에 의해 최종 결과가 정해지는 만큼 세부종목 간의 점수 특성의 관계를 파악하고, 종목별 중 요도를 파악하는 것은 기록을 관리하고 체계화하기 위한 가장 기초단계이며, 최근 국제대회에서 우수한 성적과 눈 부신 성장을 고려했을 때 국제대회 기록과 점수변화를 구 체적으로 비교하고 분석하는 연구가 이뤄져야만 한다.

이에 본 연구는 2017년부터 2019년 총 3년의 국제 근 대5종연맹 공식 기록을 비교하여 펜싱, 수영, 승마, 레이 저런 종목의 점수 특성이 최종 순위에 미치는 관계를 밝 혀내고 각 종목의 상대적 중요도를 분석하고자 한다. 특 히 본 연구는 앞으로 다가올 올림픽과 세계 대회에서 전 략 수립과 대응 방안을 위한 기초 자료 제공에 목적을 두 고자 한다.

\section{연구방법}

\section{연구자료}

본 연구는 인터넷자료를 기반으로 국제 근대5종연맹 (UIPM:International Modern Pentathlon Union)에 서 제공하는 공식 기록을 바탕으로 수영 점수 환산 방식 이 변경된 2017년을 시작으로 2019년 까지 총 3년간 UIPM Level 1 대회인 월드컵, 세계선수권대회에 출전한 남녀선수 전체를 대상으로 선정하였다.

〈Table 1〉은 예선과 결선에 출전한 선수의 수를 남녀 로 구분하여 정리한 표이다.

Table 1. Characteristics of the subjects

(N)

\begin{tabular}{ccc}
\hline \hline Competition & (1) Male & (2) Female \\
\hline (A) Final & 603 & 594 \\
\hline (B) Qualifications & 1,176 & 997 \\
\hline \hline
\end{tabular}

\section{자료수집과 측정변인}

국제 근대 5 종연맹에서는 매 경기마다 선수들의 경기
기록을 공개하고 있다. 본 연구의 자료 수집을 위하여 국 제 근대5종연맹에서 경기 기록 및 점수를 수집하였고 자 료 중 결측치를 갖는 자료는 제외하였다. 국제 근대 5 종연 맹에서 제공하는 경기 기록으로 펜싱 랭킹, 펜싱 승률, 펜 싱 환산 점수, 수영 기록, 수영 등수, 수영 환산 점수, 승 마 등수, 승마 환산 점수, 레이저런 기록, 레이저런 등수, 레이저런 환산점수를 제공하고 있다.

본 연구에서는 변수의 상대적 중요도 평가를 위해 독 립변인 4개(펜싱, 수영, 승마, 레이저런)의 점수가 종속 변인(최종등수)에 미치는 영향을 규명하고자 〈Table 2〉 와 같이 변수를 정의하였다.

Table 2. Contents and Variables

\begin{tabular}{cc}
\hline \hline Variables & Contents \\
\hline$Y$ & Final Ranking \\
\hline$X_{1}$ & Fencing Points \\
\hline$X_{2}$ & Swimming Points \\
\hline$X_{3}$ & Riding Points \\
\hline$X_{4}$ & Laser Run Points \\
\hline \hline
\end{tabular}

\section{자료분석방법}

본 연구에서 수집된 자료를 SPSS Statistics 20 프로 그램을 이용하여 각 변수에 대한 평균, 표준편차, 최소값, 최대값, 분산을 제시하고, 변수 간 Pearson의 상관분석 을 통해 다중공선성 여부를 확인하였다. 최종 등수라는 반응(종속)변수와 4개의 설명(독립)변수인 종목별 환산 점수 사이의 관계를 규명하기 위하여 다중회귀 분석 (Multiple regression analysis)을 실시하였고 모든 변 수들을 독립변수로 사용하여 일괄적으로 분석(Enter)하 는 방법을 활용했다. 또한, 예측변수들의 안정성 평가를 위해 분산팽창지수(VIF)를 제시하였는데, VIF 값이 10 이상일 때 독립변수 중 다중공선성을 의심할 수 있으며, 회귀계수의 분산을 증가시키는 문제가 발생한다.

\section{종목별 상대적 중요도 평가}

회귀분석에서 변수의 중요성 평가는 표준화 계수에 크 게 의존하고 있는데 각 설명변수에 대한 표준화 계수는 
그 변수를 제외한 모든 다른 설명변수들이 일정하게 유지 될 때, 특정 설명 변수의 표준화 된 변이 증가에 대한 반 응변수의 표준화된 변이로 해석된다(Moh et al, 2015). 표준화 계수 $(\beta)$ 는 단위가 다른 설명변수를 서로 비교해 야 할 때 표준화시켜서 계산하기 때문에, 비교의 측면에 서 간단하고 유용하게 사용할 수 있다. 따라서 본 연구에 서는 표준화 계수 $(\beta)$ 를 활용해 변수들의 상대적 중요성 평가를 실시하였고 통계상 유의수준은 .05 로 설정하였다.

또한, 서열척도의 특성을 지닌 변수를 모수통계에 사 용하는 것은 통계적 왜곡 등의 문제점을 유발할 수 있다 (Kuzon et al, 1996). 하지만 총합척도(summatedscales) 변수는 엄밀하게는 서열척도의 형태지만 등간척도형 변 수로 모수통계에서 많이 사용된다(Stevens, 1951). 회귀 분석의 가정 중 하나는 종속변수는 연속형 등간척도여야 한다는 것인데, Berry(1993)가 지적하듯이 자연적으로 완벽한 연속형 등간척도는 많지 않으며, 변수를 구성하는 각 값들의 간격이 동일하지는 않지만 불연속 등간척도에 비해 상대적으로 더 연속적인 특성을 띤 총합척도형 변수 를 종속변수로 사용해도 큰 무리가 따르지 않는다 (Michell, 2008). 본 연구에서도 선행연구를 바탕으로 서열척도인 최종 순위를 등간척도로 사용해 순위에 미치 는 상대적 중요도를 추정하고자 한다.

\section{연구결과}

\section{분석변수에 대한 기술 통계}

근대5종 세계 기록을 바탕으로 종속변수인 최종 환산 점수와 4개의 독립변수에 대한 기술통계로 최소값과 최 대값, 평균과 표준편차 결과를 결선과, 예선, 남녀로 구분 하여 〈Table 3〉과 같이 나타내었다.

\section{종목별 환산점수의 상관분석}

근대5종 세계 남자기록을 바탕으로 종목별 상대적 중 요도를 분석하기 위해서 각 변수들 간의 상관관계 분석을 실시하였다. 4 개의 독립변수(펜싱점수, 수영점수, 승마 점수, 레이저런 점수)와 종속변수(최종등수)에 대한 상
Table 3. Eigenvalues and variation by competition

\begin{tabular}{|c|c|c|c|c|c|c|c|}
\hline \multicolumn{2}{|c|}{ Competition } & \multirow{2}{*}{$\begin{array}{c}\text { Variables } \\
\mathrm{Y}\end{array}$} & \multirow{2}{*}{$\begin{array}{c}\mathrm{N} \\
603\end{array}$} & \multirow{2}{*}{$\frac{\min }{1}$} & \multirow{2}{*}{$\begin{array}{c}\max \\
36\end{array}$} & \multirow[t]{2}{*}{$\mathrm{M}$} & \multirow[t]{2}{*}{ SD } \\
\hline \multirow{10}{*}{ (A) } & & & & & & & \\
\hline & \multirow{4}{*}{ (1) } & $X_{1}$ & 603 & 136 & 282 & 204.92 & 23.08 \\
\hline & & $X_{2}$ & 603 & 255 & 323 & 296.27 & 9.01 \\
\hline & & $X_{3}$ & 603 & 191 & 300 & 284.01 & 16.75 \\
\hline & & $X_{4}$ & 603 & 472 & 670 & 604.83 & 30.13 \\
\hline & \multirow{5}{*}{ (2) } & Y & 594 & 1 & 36 & & \\
\hline & & $X_{1}$ & 594 & 136 & 276 & 205.40 & 25.51 \\
\hline & & $X_{2}$ & 594 & 208 & 299 & 271.26 & 11.90 \\
\hline & & $X_{3}$ & 594 & 204 & 300 & 282.40 & 18.41 \\
\hline & & $X_{4}$ & 594 & 337 & 608 & 518.89 & 38.06 \\
\hline \multirow{8}{*}{ (B) } & \multirow{4}{*}{ (1) } & Y & 1,176 & 1 & 35 & & \\
\hline & & $X_{1}$ & 1,176 & 114 & 278 & 205.59 & 28.47 \\
\hline & & $X_{2}$ & 1,176 & 131 & 321 & 292.77 & 15.57 \\
\hline & & $X_{4}$ & 1,176 & 128 & 667 & 576.67 & 51.163 \\
\hline & \multirow{4}{*}{ (2) } & Y & 997 & 1 & 34 & & \\
\hline & & $X_{1}$ & 997 & 107 & 298 & 205.56 & 29.92 \\
\hline & & $X_{2}$ & 997 & 165 & 298 & 265.51 & 15.91 \\
\hline & & $X_{4}$ & 997 & 135 & 599 & 483.06 & 50.41 \\
\hline
\end{tabular}

(A) Final, (B) Qualifications, (1) Male, (2) Female

관분석을 실시한 결과 〈Table 4〉에 제시된 결과와 같으 며 종속변수와 독립변수들 간에는 모두 부적 상관을 보였 는데, 이는 세부 종목의 점수가 높아질 때, 최종등수의 수 준이 부적방향으로 낮아지기 때문이다. 특히 개정 전 후, 예선, 결선 모든 부분에서 펜싱 점수가 총 등수에 높은 부 적 상관을 갖는 것을 확인하였다. 상관분석 결과 독립변 수들간의 다중공선성이 의심되는 0.8 이상 의 상관계수 가 나타나지 않아 4 개의 독립변수를 대상으로 다중회귀 분석을 실시하였다.

\section{종목별 상대적 중요도 분석}

〈Table 5〉는 근대5종 남녀 종목별 점수가 종속변수인 최종 등수에 영향을 미치는지 확인하고자 다중회귀분석 을 통해 산출된 결과를 제시한 것이다. 
Table 4. Correlations between by competition

\begin{tabular}{|c|c|c|c|c|c|c|c|}
\hline \multicolumn{2}{|c|}{ Competition } & \multirow{2}{*}{$\begin{array}{c}\text { Variables } \\
\mathrm{Y}\end{array}$} & \multirow{2}{*}{$\begin{array}{l}\mathrm{Y} \\
1\end{array}$} & \multirow{2}{*}{$X_{1}$} & \multirow[t]{2}{*}{$X_{2}$} & \multirow[t]{2}{*}{$\overline{X_{3}}$} & \multirow[t]{2}{*}{$X_{4}$} \\
\hline \multirow{10}{*}{ (A) } & \multirow{5}{*}{ (1) } & & & & & & \\
\hline & & $X_{1}$ & $-.680 * *$ & 1 & & & \\
\hline & & $X_{2}$ & $-.142^{* *}$ & $.094 *$ & 1 & & \\
\hline & & $X_{3}$ & $-.385^{* *}$ & $.117^{* *}$ & -.014 & 1 & \\
\hline & & $X_{4}$ & $-.386^{* *}$ & .027 & -.004 & $.129 * *$ & 1 \\
\hline & \multirow{5}{*}{ (2) } & $\mathrm{Y}$ & 1 & & & & \\
\hline & & $X_{1}$ & $-.538 * *$ & 1 & & & \\
\hline & & $X_{2}$ & $-.278^{* *}$ & .058 & 1 & & \\
\hline & & $X_{3}$ & $-.451^{* *}$ & .063 & .028 & 1 & \\
\hline & & $X_{4}$ & $-.478 * *$ & -.066 & .062 & .068 & 1 \\
\hline \multirow{8}{*}{ (B) } & \multirow{4}{*}{ (1) } & $\overline{Y Y}$ & 1 & & & & \\
\hline & & $X_{1}$ & $-.759 * *$ & 1 & & & \\
\hline & & $X_{2}$ & $-.332 * *$ & $.315^{* *}$ & 1 & & \\
\hline & & $X_{4}$ & $-.428 * *$ & $.251^{* *}$ & $.380 * *$ & & 1 \\
\hline & \multirow{4}{*}{ (2) } & $\mathrm{Y}$ & 1 & & & & \\
\hline & & $X_{1}$ & $-.676^{* *}$ & 1 & & & \\
\hline & & $X_{2}$ & $-.425^{* *}$ & $.232 * *$ & 1 & & \\
\hline & & $X_{4}$ & $-.489 * *$ & $.159^{* *}$ & $.277^{* *}$ & & 1 \\
\hline
\end{tabular}

(A) Final, (B) Qualifications, (1) Male, (2) Female ${ }^{*} \mathrm{p}<.05,{ }^{* *} \mathrm{p}<.01$

표에 제시된 바와 같이 독립 변수의 표준화 계수 $(\beta)$ 의 절댓값을 통해 살펴본 바 회귀식의 유의성은 결선에서 남 자는 $R^{2}=.675, \mathrm{~F}=310.144, \mathrm{p} .001$ 수준에서, 여자는 $R^{2}=.742, \mathrm{~F}=424.325, \mathrm{p} .001$ 수준에서 통계적으로 유의하게 나타났다. 예선에서 남자는 $R^{2}=.637$, $\mathrm{F}=685.489$, p.001 수준에서, 여자는 $R^{2}=.641$, $\mathrm{F}=590.466, \mathrm{p} .001$ 수준에서 통계적으로 유의하게 나타 났다. 회귀식의 유효성을 평가하기 위한 지표로서 수정된 결정계수인 $\mathrm{R}^{2}$ 이 결선 남자 $67.3 \%\left(\mathrm{R}^{2}=.673\right)$, 여자 $74.1 \%\left(\mathrm{R}^{2}=.741\right)$, 예선 남자 $63.6 \%\left(\mathrm{R}^{2}=.636\right)$, 여자 $64.1 \%\left(\mathrm{R}^{2}=.641\right)$ 로 종속변수가 가지고 있는 정보를 독 립변수(예측변수, 설명변수)의 변동이 설명하고 있다. 표 준화 계수 $(\beta)$ 를 활용해 종목별 점수 및 기록이 최종 점수 에 미치는 영향력 크기 순위는 결선에서 남자는 펜싱 $(\beta$ $=-.632)$, 레이저런 $(\beta=-.334)$, 승마 $(\beta=-.269)$, 수영
Table 5. Multiple regression analysis by competition

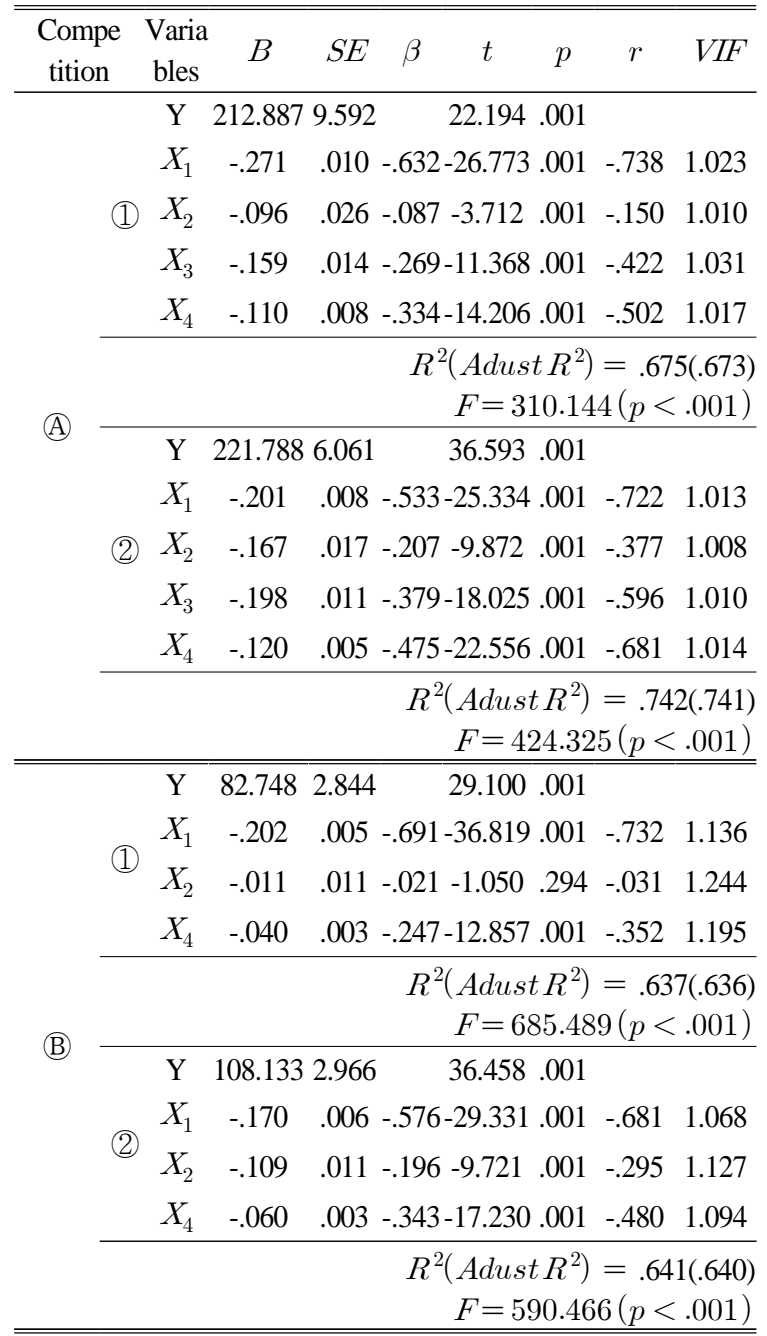

(A) Final, (B) Qualifications, (1) Male, (2) Female

$r$ : Partial correlation coefficient

( $\beta=-$.087)이며, 여자는 펜싱 $(\beta=-.533)$, 레이저런 $(\beta$ $=-.475)$, 승마 $(\beta=-.379)$, 수영 $(\beta=-.207)$ 순으로 남 녀 모두 같았으며 4 개의 독립변수 모두 유의미한 변수들 로 확인되었다. 예선에서도 남녀 모두 같은 결과가 나왔 는데 남자는 펜싱 $(\beta=-.691)$, 레이저런( $\beta=-.247)$, 수 영 $(\beta=-.021)$, 여자는 펜싱 $(\beta=-.576)$, 레이저런 $(\beta$ $=-.343)$, 수영 $(\beta=-.196)$ 순으로 남자 수영을 제외한 독 립변수 모두 유의미한 변수들로 확인되었다. 〈Figure 1〉 은 결선과 예선의 독립변수들의 표준화 계수( $\beta)$ 분포를 


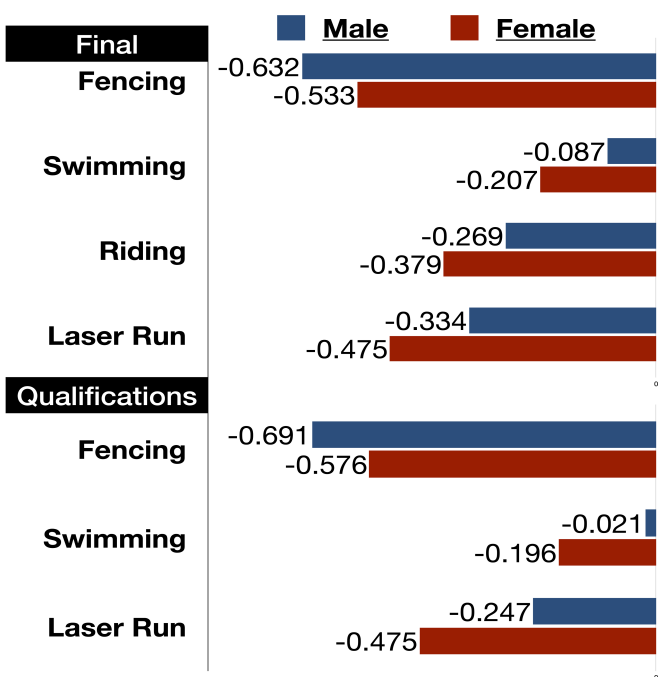

Fig. 1. Determining the relative importance $(\beta)$ by competition

나타낸 그래프이며, 〈Figure 2〉, 〈Figure 3〉, 〈Figure $4\rangle$, 〈Figure 5$\rangle$ 는 주요 국가별 각 세부종목의 점수 획득 분포를 나타낸 그래프이다.

\section{논의}

본 연구는 2017년부터 2019년까지 국제 근대5종연맹 에서 제공하는 세계대회 공식 경기 기록을 바탕으로 근대 5 종 세부종목별 점수와 최종 등수의 관계를 규명하고 표 준화계수를 활용해 세부 종목의 상대적 중요도를 비교하 고자 하였다.

$\operatorname{Heck}$ (2014)는 2012년 런던올림픽 이후 근대5종이 올림픽에서 생존하기 위한 방법으로 기초체력 종목인 육 상과 수영의 중요성을 강조한 바 있는데, 기초체력이 중 심인 종목의 경우 점수 특성과 체계에 따라 선수 간 경기 력의 차이는 줄어든다고 강조했다. 또한 Parisi et $\mathrm{al}(2015)$ 의 연구에서도 근대5종 대회에서 나타나는 기 록은 오랜 시간에 걸쳐서 연마된 기초체력 중심의 훈련방 법을 통해 나타나는 결과라 제시한 바 있다. Park \& Lee(2020)는 세계대회에서의 사격 기록을 분석한 연구 에서 레이저런 종목의 기량 향상과 중요성을 제언했으며,

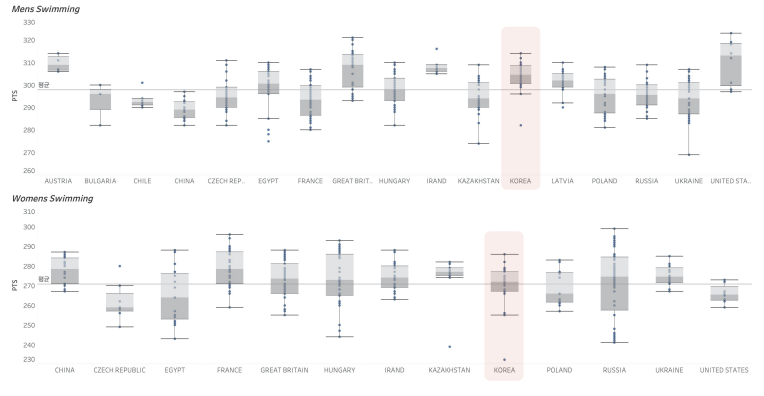

Fig. 2. Swimming points by country

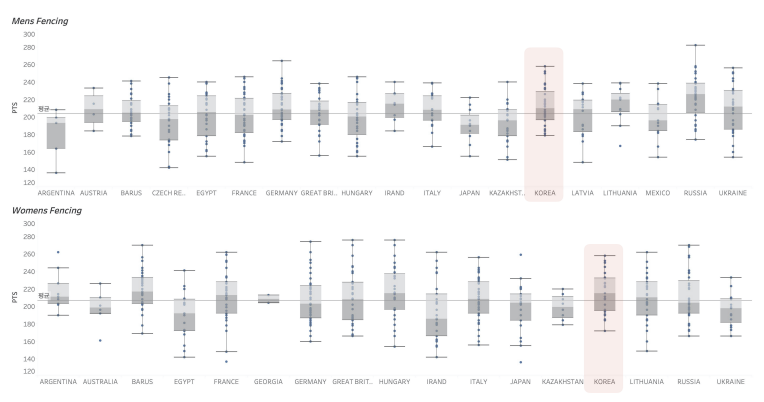

Fig. 3. Fencing points by country

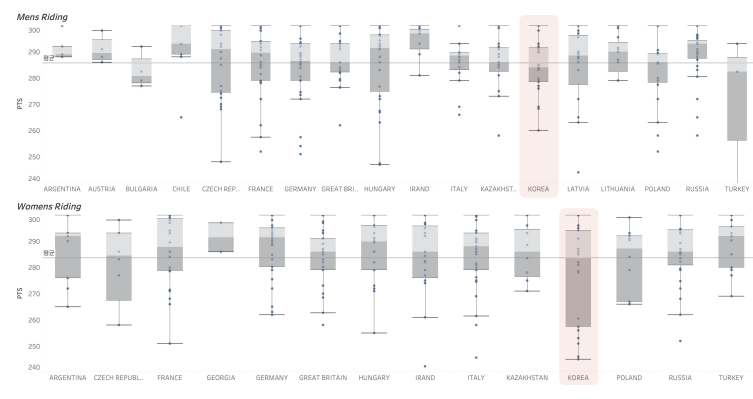

Fig. 4. Riding points by country

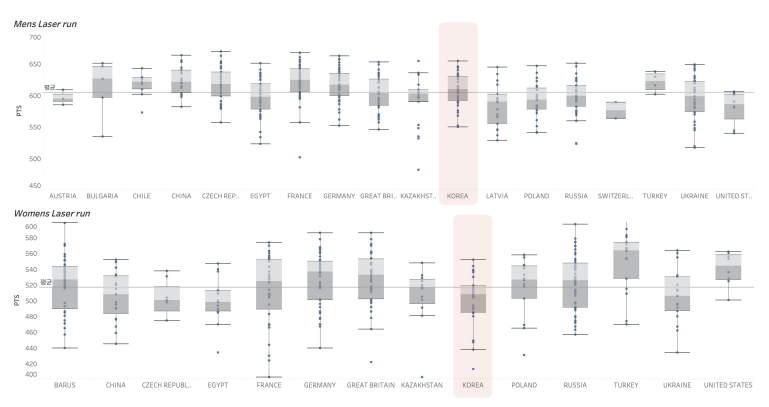

Fig 5. Laser-run points by country 
Han \& Choi (2016)는 국내 근대5종 선수들을 대상으로 상위그룹과 하위그룹의 비교 연구를 통해 수영, 승마, 육 상 종목의 기록에서 두 그룹 간 통계적으로 유의한 차이 가 나타나지 않았다고 보고하며 기초체력 종목의 중요성 을 강조했다. Le Meur et al(2010)은 기초체력이 중심 인 종목(육상, 수영)에 비해 기술적 요소가 중심인 종목 (펜싱, 사격)에서 기량차이가 많이 벌어질 수도 있으며, 체계적이고 다양한 보완책이 마련되어야 경기력 향상을 가져올 수 있다고 제언한 바 있다. 이와 같이 근대 5 종은 전통적으로 고수해온 기초체력 종목이 중심이 되어야 하 지만 최근 기록을 살펴보면 기술적 요소가 중심인 종목의 중요성이 더욱 강조되고 있다(Fonseca et al, 2014).

이 연구에서도 펜싱 종목은 예선과 결선 모두에서 그 중요도가 가장 높게 나타난데 비해 수영 종목의 중요도는 예선 결선 모두 가장 낮게 나타나는 결과를 통해 앞선 주 장을 뒷받침한다. 이는 펜싱이 유일한 상대성 종목 특성 으로 정해져있는 점수를 참가 선수들이 나눠 갖는 환산 방식에 따라 등수와의 영향도가 크다고 할 수 있다. 결선 에서는 남녀 모두 예선에 비해 펜싱 영향력이 줄어들었는 데 이는 결선에서 선수들의 실력이 평준화된 영향이 크며 독립변수(승마 점수)의 추가에 따른 표준화 계수 수치가 하향되었기 때문이다. 이에 비해 레이저런의 경우 남녀 모두 예선 영향력에 비해 결선 영향력이 오히려 늘어났 다. 이는 레이저런의 경우 예선 마지막 종목이며 특정 등 수 내에만 들어오면 결선 진출이 가능하기에 최선의 경쟁 이 펼쳐지지 않아 상대적 중요도가 저평가 되었을 가능성 이 있다. 하지만 결선에서는 마지막 종목인 레이저런 순 위가 최종 순위로 연결되는 만큼 최선의 경쟁이 펼쳐져 상대적 중요도가 올라갔다고 판단된다. 수영 점수의 경우 최종 등수에 미치는 영향이 남녀 모두 가장 낮게 나타났 다. 특히 예선전 수영 점수의 영향력이 결선에서 영향력 에 비해 남녀 모두 낮게 나타났다. 즉 예선 결선 모두 수 영 점수가 최종 성적으로 연결되는 데는 한계가 있었고, 이는 2017년 기존 3점(1초당)의 점수 차를 2점(1초당) 으로 점수 환산방식의 변경에 따른 변별력이 낮아져 최종 점수에 미치는 영향이 미비함이 원인으로 작용한 것으로 판단된다.

최근 대한민국 근대 5 종은 세계선수권대회나 월드컵, 아시안게임에서 우승을 거두는 등 경기력 수준이 과거에
비해 비약적인 발전을 이루면서 전성기를 맞이하고 있다. 그러나 지속적인 정상 수준을 유지하지 못하며 올림픽경 기에서는 메달 획득에 번번이 실패하고 있다. Fig 2 와 같 이 대한민국 대표팀은 최근 3년 세계대회 남녀 모두 수영 점수는 상위권을 유지하고 있다. 이는 국내의 경우 기초 체력 종목인 수영과 육상종목을 최우선으로 육성하고 있 으며 수영을 잘하는 선수 위주로 선발(Han \& Choi, 2016)하기 때문에 세계대회에서도 수영종목은 꾸준히 좋은 결과로 이어진다고 사료 된다. 특히 수영 종목은 국 가 대표 선수들의 점수 편차도 크지 않아 기복이 작으며 지속적으로 높은 경기력을 유지하고 있다. 하지만 Han \& Choi(2016)는 앞선 연구에서 밝혔듯이 기초 체력이 중심인 육상과 수영 종목 기량 향상이 상, 하위 그룹 간 비교적 차이가 나타나지 않는다고 했을 때, 세계적으로 높은 경기력을 유지하기 위해서는 기술과 기능이 중심인 펜싱, 승마, 사격 종목의 경기력을 향상 시키는 방안이 고 려되어야 한다고 제언한바 있다. Lee \& An(2012)은 세 계선수들의 기록을 토대로 국내외 근대5종 기록 추이를 연구한 바 있다. 세계적인 선수들에 비해 국내 선수들의 경기력은 꾸준히 유지되지 않는다고 제언했는데, 그 원인 으로 기록 변화의 폭이 크다는 것을 지적했다. 〈Figure 4 , 〈Figure 5〉와 같이 대한민국 대표팀의 승마, 레이저 런 점수는 남녀모두 중상위권을 유지하고 있지만 점수의 편차가 커 기복이 심함을 알 수 있다. 특히 여자 승마 종 목의 점수 편차가 크고 여자 레이저런 종목의 평균 점수 가 낮게 형성되어 있음을 알 수 있다. 반면 Fig 3 과 같이 남자 펜싱의 경우 높은 점수로 상위권을 유지하고 있으 며, 여자도 중상위권을 유지하고 있다. 세계기록을 바탕 으로 앞서 제시한 펜싱의 상대적 중요도를 고려했을 때 대한민국 대표팀의 펜싱경기력은 고무적으로 판단된다. 세계대회 결승전을 기준으로 펜싱종목 1승의 가치는 수 영에서 3 초, 승마는 장애물 하나의 낙마, 레이저런은 6 초 로 다른 종목 기록으로 환산가능하다. 이는 펜싱 종목에 서 높은 점수를 획득하지 못하면 세계대회 상위권 입상이 어려워지며, 다른 종목에서 만회하기가 쉽지 않다는 의미 이다. 대한민국 대표팀의 최근 경기결과를 비교해보면 상 위권에 입상했을 때 항상 펜싱 성적이 좋았음을 알 수 있 는데, 이는 앞으로도 계속 이어질 것으로 판단된다.

최근 세계대회에 출전하는 선수들의 펜싱 경기력은 상 
향 조정되고 있는 추세이며 고득점을 얻는 선수들이 많아 지고 있다. 근대5종 펜싱은 주어진 시간 내 상대와 단판 승부를 펼치며 한 번의 공격으로 끝나는 경우가 대부분이 라 상대에 대한 특성 파악과 기술 분석이 중요하다 (Skitnevskiy, 2018). 따라서 세계대회에서 좋은 성적 을 거두기 위해서는 펜싱종목의 경기력 향상을 통해 승률 을 올리기 위한 다양한 노력이 필요하며, 세계 우수 선수 들의 펜싱기술에 대한 철저한 분석을 통해 우리나라 대표 선수들이 올림픽을 포함한 국제대회에서 우수한 경기력 을 지속적으로 유지 하는데 도움을 줄 수 있을 것으로 사 료된다.

\section{결론 및 제언}

본 연구는 2017년부터 2019년까지 국제 근대5종연맹 에서 제공하는 공식 경기 기록을 바탕으로 근대5종 세부 종목(펜싱, 수영, 승마, 레이저런)별 점수와 최종 등수의 관계를 규명하고 세부 종목의 상대적 중요도를 비교하는 데 목적이 있었다. 본 연구의 결과를 토대로 내린 결론은 다음과 같다.

첫째, 근대 5 종 세부종목별 환산 점수와 최종 등수간의 관계를 알아보기 위하여 다중회귀분석을 실시한 결과 남 녀 모두 펜싱, 수영(결선), 승마(결선), 레이저런 점수 요 인이 최종 성적에 유의한 영향을 미치는 것으로 확인되었 고 남자 예선전 수영의 경우 최종 성적에 유의한 영향을 미치지 않는 것으로 확인되었다.

둘째, 세부종목별 상대적 중요도를 비교한 결과 남녀 모두 결선은 펜싱, 레이저런, 승마, 수영 순이며, 예선은 펜싱, 레이저런, 수영 순으로 나타났다. 특히 펜싱은 남녀 모두에게 예선과 결선에서 가장 높은 영향력을 보였으며 수영은 예선과 결선 모두 가장 낮은 영향력을 보였다.

셋째, 근대5종 최근 기록을 바탕으로 살펴본 결과 기 초체력 위주 종목 보다 기술적 요소가 중심인 종목의 중 요성이 더욱 강조되고 있으며 예선과 결선 모두에서 유일 한 상대성 종목이며 기술적 요소가 중요한 펜싱의 중요도 가 높음을 확인할 수 있었다.

펜싱경기력 향상을 위해 우리나라 선수들을 포함한 세 계 우수 선수들의 펜싱기술을 분석하고 체계화 하는 것이
필요하며, 이런 과학적 분석 자료를 통해 다가올 올림픽 현장에서 빠르고 유연한 대응이 가능한 시스템을 구축해 야 된다. 또한 근대 5 종의 복합경기 특성상 모든 종목의 중요도는 평준화 되어야 함에도 불구하고 상대적 중요도 가 펜싱종목에 편향되어 있으며 수영종목은 등한시되어 있다. 따라서 근대 5 종 경기에서 점수체계가 각 종목의 기 록과 상하위권 점수체계를 뒷받침할 수 있는 점수체계로 구성되어 있는지에 대한 후속연구가 필요하다고 사료된 다.

\section{참고문헌}

Berry, W. D. (1993). Understanding regression assumptions (Vol. 92). Sage Publications.

Chirico, A., Fegatelli, D., Galli, F., Mallia, L., Alivernini, F., Cordone, S. \& Lucidi, F. (2019). A study of quiet eye's phenomenon in the shooting section of "laser run" of modern pentathlon. Journal of cellular physiology, 234(6), 9247-9254.

Choi, H. J. \& LEE, Y. S. (2020). The big data analytics for performance analysis of tennis. The Korean Journal of Measurement and Evaluation in Physical Education and Sport Science, 22(1), 57-68

Cohal, D. C. (2019). The History of pentathlon competitions. In international conference knowledge-based organization. Sciendo, 25(2), 234-239.

Fonseca, J., Loureiro, L. L., Feital, E. M. \& Pierucci, A. P. T. (2014). Impact of detraining on anthropometry of adolescent pentathletes. Revista Brasileira de Medicina do Esporte, 20(5), 398-401.

Han, D. R. \& Choi, H. J. (2016). Comparisons of performances before and after the rule changes in the Modern Pentathlon. The Korean Journal of Physical Education, 55(4), 541-550

Han, D. R. (2009). An exploration on the recovery of the instructor's ethics in modern pentathlon, doctoral dissertation, Korea National Sport University, Seoul.

Heck, S. (2014). A sport for everyone? inclusion and exclusion in the organisation of the first olympic modern pentathlon. The International Journal of the History of Sport, 31(5), 526-541.

Hughes, M. \& Franks, I. M. (2004). Notational analysis of sport; second edition. London: Routledge. 
Kim, J. H. \& Choi, H. J. (2008). Reinterpretation of winning and Losing performances based on different data ranges. Korean Journal of Measurement and Evaluation in Physical Education and Sport Science, 17(1), 1-12

Korea Modern Pentathlon Federration. (2018) UIPM competition rules and regulations Guidelines. 2018. Available online: http://www.pentathlon.or.kr/upload/rule/uipm_comp_rules_a nd_reg_2018_a5_v2.pdf(accessed on 7 May 2020).

Kuzon, W. M., Urbanchek, M. G. \& McCabe, S. (1996). The seven deadly sins of statistical analysis. annals of plasticsurgery, 37, 265-272.

Le Meur, Y., Hausswirth, C., Abbiss, C., Baup, Y., \& Dorel, S. (2010). Performance factors in the new combined event of modern pentathlon. Journal of sports sciences, 28(10), 1111-1116.

Lee, S. I. \& An, C. S. (2012). The comparative study of shooting, swimming, track and field between world record and national record in modern pentathlon players. The Korean Journal of Sport, 10(1), 157-163

Michell, J. (2008). Is psychometrics pathological science?. Measurement. 6(1/2), 7-24.

Moh, Y. S., Han, S. T., Yeon, K. P. \& Kang, H. C. (2015). Astudy on variable importance measuresin multiple regression analysis. Journal of The Korean Data Analysis Society, 17(6), 2981-2990.

Parisi, A., Tranchita, E., Magini, V., Fabrizi, E., Cerulli, C., \& Cardelli, G. (2015). The evolution of modern pentathlon following the introduction of the latest changes to the rules. Medicina dello Sport, 68(1), 121-7.

Park, J. C. \& Lee, S. H. (2020). The analysis of game outcomes based on UIPM shooting match data in the modern pentathlon. Journal of Digital Convergence, 18(6), 523-529,
Park, K. D., Yeon, D. J. \& Choi, S. A. (2017). The life of Mr. choi kui-sung and modern pentathlon history of korea. Korean Journal of Sport Studies, 56(1), 471-486.

Pentathlon, O. M. (2015). Analysis of the role of horse riding in the program of modern pentathlon, based on morphological and functional and psychological characteristics of yong athletes. Modern University Sport Science, 9.

Sandra H, (2013) Modern pentathlon at the London 2012 olympics: Between traditional heritage and modern changes for survival. The International Journal of the History of Sport, 30(7), 719-735.

Sandra H, (2014). Asport for everyone? Inclusion and exclusion in the organisation of the first olympic modern pentathlon. The International Journal of the History of Sport, 31(5), 526-541.

Skitnevskiy, V. L., Balashova, V. F., Novozhilova, Y. S., Sedov, I. A., Lebedkina, M. V. \& Grigoryeva, E. L. (2018). Integral scoring system of workout sessions in modern pentathlon. www.mjltm.cominfo@mjltm.org, 73.

Stevens, S. S. (1951). Mathematics, measurement and psychophysics. In S. S. Stevens. (Ed.) Handbook of Experimental Psychology. NewYork: Wiley.

UIPM. (2017). https://www.uipmworld.org/search?search_phrase =rule.

Kim, H. J., Kang, T. Y., An, C. S. \& Kim, M. S. (2018). A policy recommendations for the development of the modern pentathlon. Korean Society Of Sport Policy, 44, 103-122. 


\title{
근대5종 세계기록 비교를 통한 세부 종목별 상대적 중요도 분석
}

\author{
이승훈 ${ }^{1}$, 박종철 ${ }^{2}$, 김기범 ${ }^{1}$, 고병구 ${ }^{3}$, 김성진 $^{4}$ \\ ${ }^{1}$ 한국스포츠정책과학원 분석연구원 \\ 2부경대학교 해양스포츠학과 조교수 \\ 3한국스포츠정책과학원 수석연구위원 \\ ${ }^{4}$ 대한근대5종연맹 대표팀 지도자
}

〔목적〕 본 연구는 최근 3년의 UIPM 공식 세계기록을 비교하여 펜싱, 수영, 승마, 레이저런 종목의 점수 특성이 최종 순위에 미치는 관계를 밝혀내고 각 종목의 상대적 중요도를 분석하고자 한다. 〔방법) 2017년에 서 2019년 까지 총 3년간 UIPM Level 1 대회인 월드컵, 세계선수권대회에 출전한 남녀선수 전체(결선 1,197 건, 예선 2,173건)를 대상으로 최종 등수, 펜싱 환산 점수, 수영 환산 점수, 승마 환산 점수, 레이저런 환산 점수 총 5 개의 자료를 수집하여 최종 등수라는 반응(종속)변수와 4 개의 설명(독립)변수인 종목별 환산 점수 사이의 관계를 규명하기 위하여 다중회귀 분석을 실시하여 효과를 검증하였다. 〔결과〕 본 연구에서는 남자 $(n=1179)$, 여자 $(n=1591)$ 로 나누어 예선 $(n=2173)$, 결선 $(n=1197)$ 별로 비교한 결과 펜싱 점수가 예선(남자 $\beta=-.691$, 여자 $\beta=-.533$ )과 결선(남자 $\beta=-.632$, 여자 $\beta=-.632$ )모두에서 가장 큰 영향력을 나타냈으며, 반대로 수영점수가 예선(남자 $\beta=-.021$, 여자 $\beta=-.196$ )과 결선(남자 $\beta=-.087$, 여자 $\beta$ $=-$.207)모두에서 가장 낮은 영향력을 나타냈다. 펜싱 종목은 예선 통과 여부의 큰 역할을 담당하고 있고, 결선에서 좋은 성적에 큰 변수로 작용하고 있는데 반면 수영 점수의 경우 최종 등수에 미치는 영향이 남녀 모두 가장 낮았고, 예선 결선 모두 수영 점수가 최종 성적으로 연결되는 데는 한계가 있다. 〔결론) 결론적으로 펜싱경기력 향상을 위해 우리나라 선수들을 포함한 세계 우수 선수들의 펜싱기술을 분석하고 체계화 하는 것 이 필요하며, 이런 과학적 분석 자료를 통해 다가올 올림픽 현장에서 빠르고 유연한 대응이 가능한 시스템을 구축해야 된다. 또한 근대 5 종의 복합경기 특성상 모든 종목의 중요도는 평준화 되어야 함에도 불구하고 상대 적 중요도가 펜싱종목에 편향되어 있으며 수영종목은 등한시되어있다. 따라서 근대5종경기에서 점수체계가 각 종목의 기록과 상하위권 점수체계를 뒷받침할 수 있는 점수체계로 구성되어 있는지에 대한 후속연구가 필 요하다고 사료된다.

주요어: 근대5종, 엘리트 선수, 상대적 중요도, 스포츠 경기 분석, 스포츠 빅데이터 